\title{
SOME RELATIONSHIPS ASSOCIATED WITH THE BROWN FIBRE INDUSTRY OF SRI LANKA
}

\author{
By \\ S. B. Ratnayake ${ }^{1}$
}

\begin{abstract}
Export onented brownfibre industry of Sn Lanka has been sustained during the last two decades with periodic fluctuations in the annual voluntes, showing a nett decline towards later years. The level of export volume in the past years show a strong correlation with the number of drought days in the coconut area during the particular year. The increased exportscan be expected to result in withdrawal of husk available for application in moisture conservation of the cultivated lands. Yhe effect would be aggravated by most exports being effected in the drought years. High incidence offibre expons, as it seenu when viewed against the annual crop pattern, lead to a drop in the harvests of thefollowing years. Means of avoiding the damage, thus caused while maintaining a satisfactory level of exports, maybe the primary factor to be concerned with, in planning future development programmes.
\end{abstract}

\section{INTRODUCTION}

In Sri Lanka, coconut husk is used as a raw material for the manufacture of coir and other fibre based products. The inclustry has been well documented by several authors in the past (Tropical Products Institute, 1970). Husk and its products are also highly recommended for soil and moisture conservation in coconut lands (Shanmugan, 1970 and Coconut Research Institute, 1990). Interaction of the supplies available for two applications in the recent past, is evident from the statistical publications of the agencies concerned with the coconut inclustry of Sri Lanka (Coconut Development Authority, 1984 and 1993; Ministry of Plantation Industries, 1993).

\section{METHODOLOGY}

A computer aided analysis was carried out to study any correlations between the annual changes of quantities of brown fibre exported, income generated, drought patterns of coconut growing areas and the annual yields of coconut as given in the authoritative statistical publ ications for the period 1974 to 1992.

\section{RESULT AND DISCUSSION}

Brown fibre in Sri Lanka is a labour intensive, export oriented industry that utilizes the fibrous mesocarp (husk) of the coconut as the raw material. Variety of serni-finished commodities such as bristle fibre, mattress fibre, twisted fibre and coir yarn are manufactured out of the ligneous fibres of the coconut husk. This finds application as a low cost material that can be used in a wide variety of products such as upholstery, car cushions, brushes, hop lines, geotextiles and even as a thermal insulation material at low temperature.

In this study, the export volumes of Sri Lanka is treated as a whole, giving attention to the gross effects beneficial or otherwise to the economy of the coconut sector. While export of fibre products bring in valuable revenue to the sector, the raw material utilized also has its local use as an indispensable soil conditioner in the coconut triangle of the country where the plantations are often subjected to moisture stress during certain periods of the year.

\footnotetext{
${ }^{1}$ Deputy Director (Quality Control) Coconut Development Authority, 54 Nawala Rd, Colombo 5, Sri Lanka.
} 
The husk used in the fibre industry is about 2 to 6 months stale after the day of harvest, thus the tissues being dead and subjected to all the natural enzymatic changes by the time these are processed. The husk being usually dry and hard is subjected to soaking for a few weeks, thus conditioned for extraction of fibre. The mechanical extraction of fibre is carried out by holding against revolving nailed drums in a number of stages, a manual operation that is associated with high risk and requires a special skill to maintain a high level of productivity. The mechanism of extracting has its unique advantage of neatly separating different fibers, of varying lengths and sizes so as to obtain well sorted grades of 'bristle', 'mattress ', 'O-mat' and baby grades of fibres separated from the matrix tissue of coir pith. The purity and uniformity of different grades is ftirther improved by sifting the manual combing of longer fibers. However, separation of ultimate particles of adhering coir pith is achieved only by drying of the fibre, which is an important step to ensure market acceptability through removal of the dead weight of water that could even lead to rapid degeneration of the product quality.

Manufacture of quality fiber thus depends on the facilities available for drying. Coir being a low cost product use of any fuels for drying is precluded. Dehydration of the material is thus almost always carried out by exposure to sunlight. Dry spells are so important to the fibre industry, that statistics in the past years show that there is a very high correlation between the number of dry days in a given year and the quantity of fibre exported (Please see Chart 1). Correlation coefficient of 0.774 is so significant that this could be identified as the most predominant factor that regulates the volume of fibre exported.

Sri Lanka being the largest exporter of brown fibre, one would expect that income from fibre would depend on the supply demand principles. Contrary to the generally expected tendency for the prices to increase with shortages in supply and vice versa, statistics in the past show that the U.S. dollar income accrued mostly depends on the quantities marketed only (Please see chart 2).

This may give the inference that markets have always remained a buyers market, being a low priced product perhaps made attractive and workable to the supplier entirely due to the change in Rupee value of the dollar. Please see chart 3 which shows an increase in rupee income over the years with a slight decline in the quantities exported over the period of time.

The chart shows a variation in quantities exported from year to year, likely to be associated with the most significant factor, the weather patterns as indicated before. However, the ups and downs of the fibre industry also appears to exert a determinative effect on the crop pattern. Chart 4 shows that a negative correlation exists between the change in exports of fibre from year to year and the increase or decrease of the crop (quantity of coconuts produced) of the following year.

The influence of fibre export volumes on the crop of the following years cannot be a mere accident as the same raw material is used to minimize moisture stress and improve the coconut soils. The period taken for the effect to show up from the time of export may vary from 1 to 2 years, depending on the time taken for husks to be conditioned prior to extraction and the storage time of fibre prior to export. Statistics show that more fibre is exported in the years of prolonged spells of dry days; the pefiod where moisture stress is most probable in the coconut growing areas. This combination of events tend to compound the ill effects as the husk supply for use in the plantation solls is minimized when it is needed most through increased demand of the raw material for the fibre industry. This could lead to the beginning of a vicious cycle that would be detrimental to the fibre industry itself and the other areas of the coconut processing industry. The chart shows that the negative effect is more pronounced in the later years.

The question would thus arise as to how the fibre industry can coexist with other priorities of the coconut sector. What is the sustainable level of fibre extraction under given circumstances such as changing weather patterns? How to make the maximum with the optimal level of utilization to 
maintain the industry at a viable level? Over the years there appears to be an increase in value added products from fibre, associated. with a slight decline in fibre exports. Further studies are essential to ascertain whether adequate progress has been achieved in this direction and the constraints that has to be overcome for better results.

If any assistance is planned for the development of the fibre industry, this has to be backed by a technological foundation that facilitates the following parwneters.

1. Overcome obligatory dependence on fair weather.

2. Maximum value addition to match market needs.

3. Stringent quality assurance programmes to ensure market stability and overcome buyers dominance.

4. Recycling of biomass from the industry to plantations.

Further reference is made to the parameter 4 in the light of increasing demand for the by-product, coir p1 th as a soil conditioner. nough expeniments have indicated that this could replace the husk for conditioning of coconut soils, the demand for export of the sarne is also in the increase. Besides, attention has to be drawn to recycle all waste material of the fibre industry back to the plantation soils, with effective techniques of application worked out. This may also relieve the burden on the fibre mills having to deal with large volumes of waste material.

Considering the interwoven web of interactions and the significance of the interacting interests towards sustenance of the industry, the necessity for a carefully worked out plan cannot be over emphasized.

\section{REFERENCES}

Tropical Products Institute 1970. The preparation of coir or coconut fibre by traditional methods. (TPI Report G52)

SHANMUGAM, K. S. 1970, Coconut husks best to bury. Cocon. Bull. 1 (5) 3-6 illus.

Coconut Research Institute Advisory Circular Leaflet Nos. A7 to A9 1990. Soil and moisture conservation of coconut lands.

Coconut Development Authority 1993, Sri Lanka Coconut Statistics for 1992

Ministry of Coconut Industries, Coconut Development Authority 1985. Sri Lanka Coconut Statistics 1984.

Ministry of Plantation Industries, Planning Division 1993. Plantation Sector Statistics Pocket Book 1993.

Fibre Products Exports 1975-1992

Effect of the annual dry spells 


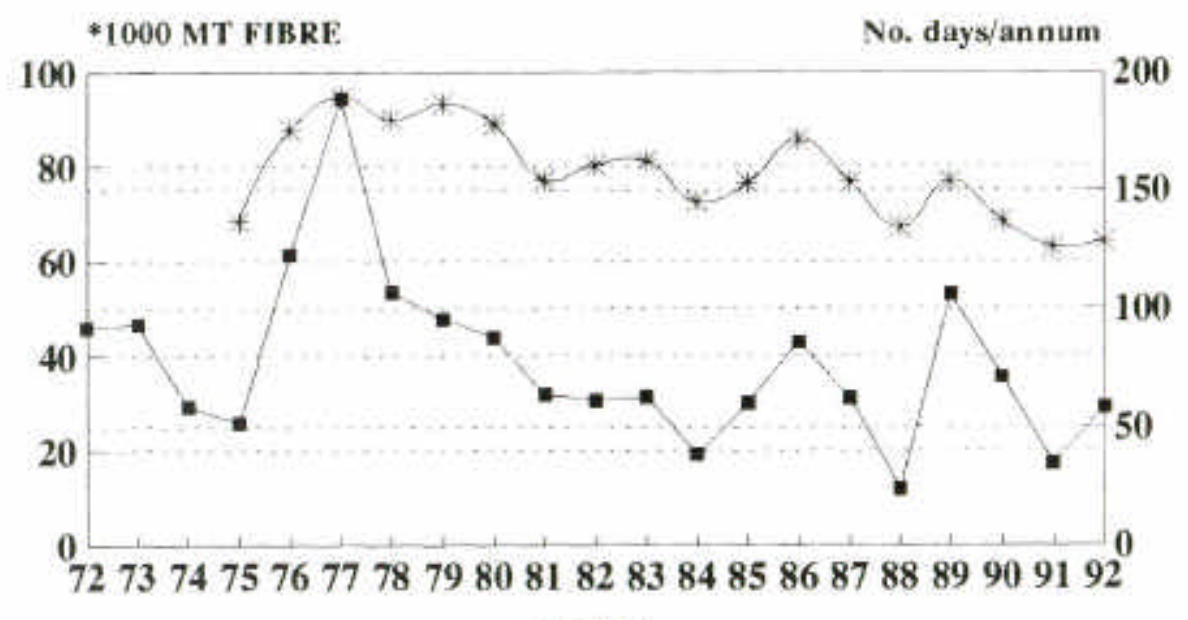

YEAR

CHART NO: 1 .

* NKP Exports - DROUGHT DAYS

There is a correlation between exports

and the number of dry days of the year.

Correlation coef $=0.774$ [CDA statistics]

\section{EXPORT OF FIBRE AND YARN AND ANNUAL INCOME 1975-92}

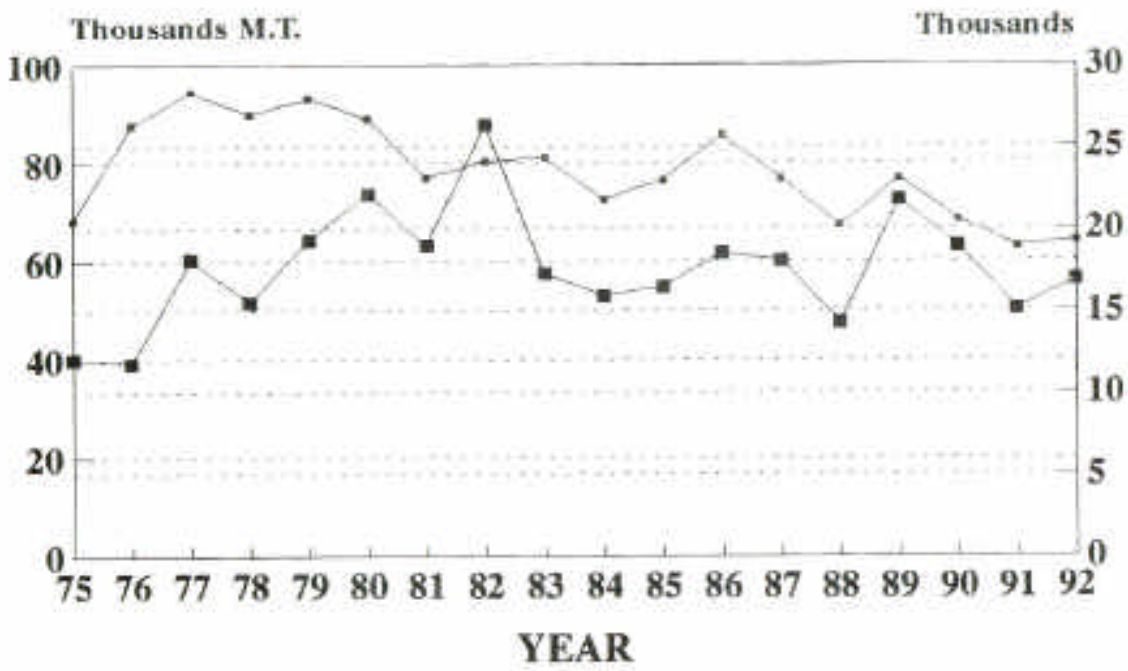

- VOLUME EXPORT - INCOME IN S/ANNUM

SOURCK: Coconut Development Authority

CHART NO: 2 


\section{EXPORT OF FIBRE AND YARN AND INCOME/M.T. IN Rs. 1975-92}

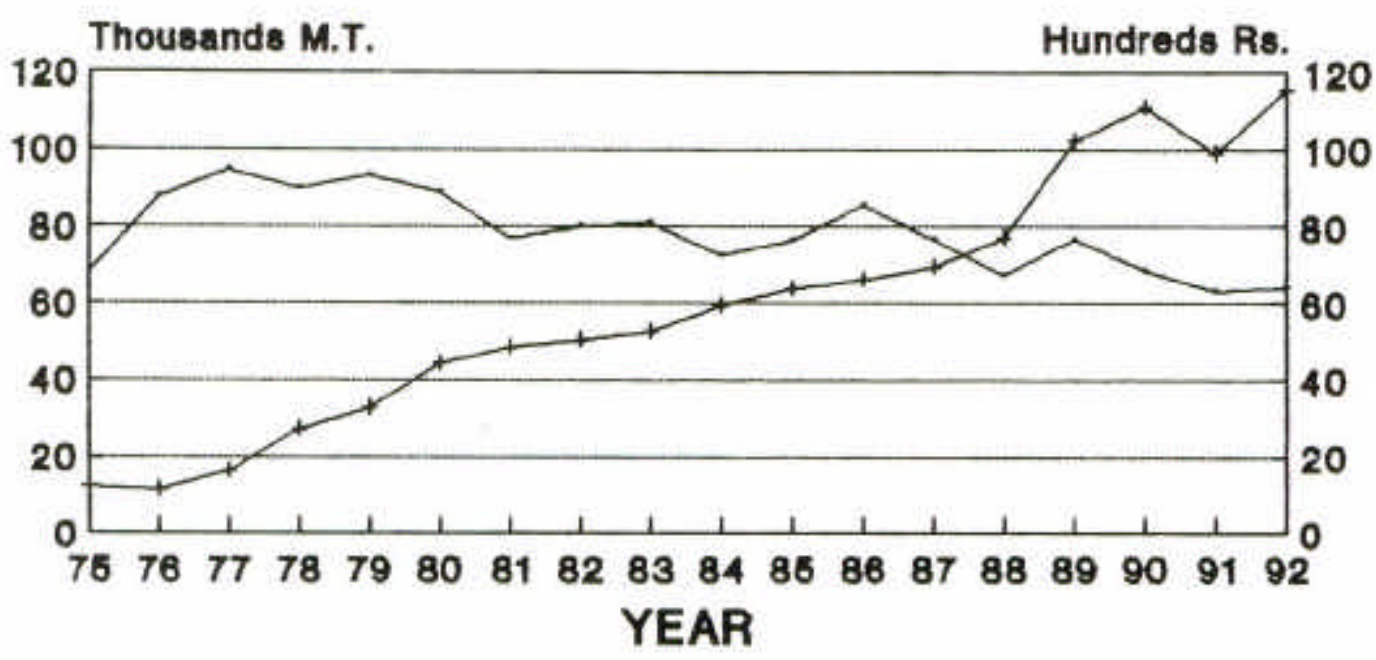

- VOLUME EXPORT — FOB PRICE

Correlation coeffloient -0.682

CHART NO: 3

Bource: Coconut Development Authority

\section{CUMULATIVE ANNUAL DIFFERENCES 1976-92}

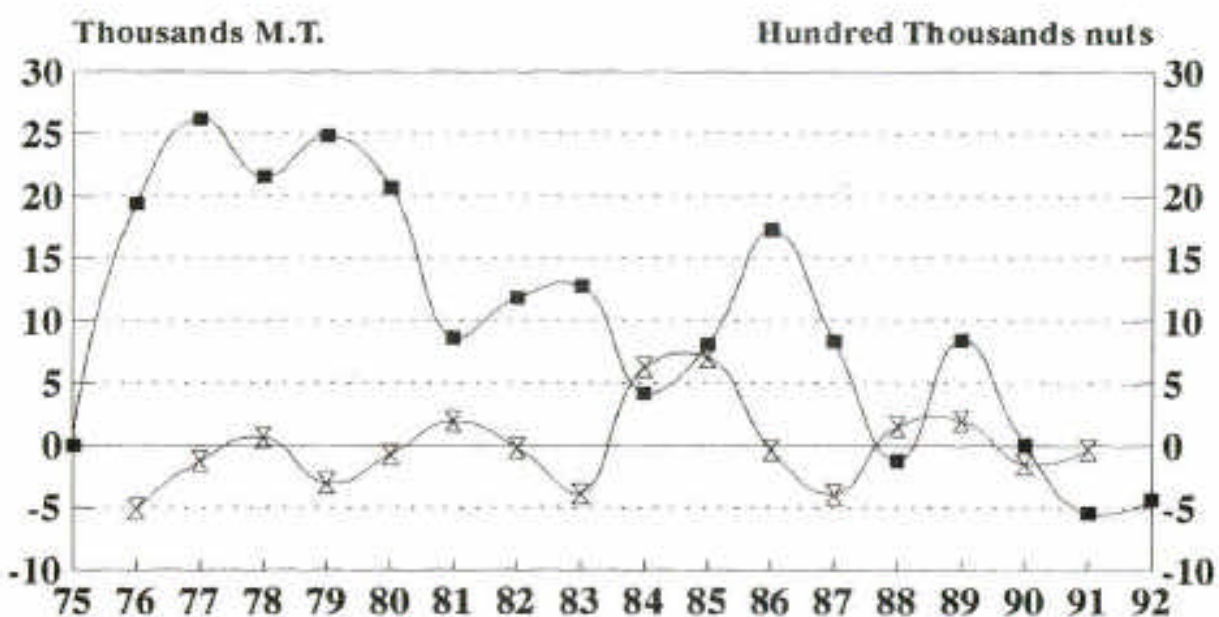

year

CHART NO: 4

- CHANGE IN VOLUME $₹$ CHANGE IN HARVEST

Source: Coconut Development Authority 